\title{
Latent class analysis for identification of occupational accident casualty profiles in the selected Polish manufacturing sector
}

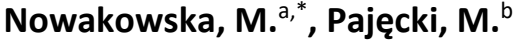 \\ aFaculty of Management and Computer Modelling, Kielce University of Technology, Poland \\ ${ }^{\mathrm{b}}$ Faculty of Management and Computer Modelling, Kielce University of Technology, Poland
}

\begin{abstract}
A B S T R A C T
The objective of the analysis is identifying profiles of occupational accident casualties as regards production companies to provide the necessary knowledge to facilitate the preparation and management of a safe work environment. Qualitative data characterizing employees injured in accidents registered in Polish wood processing plants over a period of 10 years were the subject of the research. The latent class analysis (LCA) method was employed in the investigation. This statistical modelling technique, based on the values of selected indicators (observed variables) divides the data set into separate groups, called latent classes, which enable the definition of patterns. A procedure which supports the decision as regards the number of classes was presented. The procedure considers the quality of the LCA model and the distinguishability of the classes. Moreover, a method of assessing the importance of indicators in the patterns description was proposed. Seven latent classes were obtained and illustrated by the heat map, which enabled the profiles identification. They were labelled as follows: very serious, serious, moderate, minor (three latent classes), slight. Some recommendations were made regarding the circumstances of occupational accidents with the most severe consequences for the casualties.
\end{abstract}

\section{ARTICLE INFO}

Keywords:

Manufacturing industry;

Occupational accidents;

Accident profiles identification

Modelling;

Latent class analysis (LCA);

Cluster analysis;

Model selection

*Corresponding author:

spimn@tu.kielce.pl

(Nowakowska, M.)

Article history:

Received 24 June 2021

Revised 5 December 2021

Accepted 6 December 2021

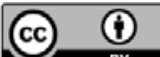

Content from this work may be used under the terms of the Creative Commons Attribution 4.0 International

Licence (CC BY 4.0) Any further distribution of this work must maintain attribution to the author(s) and the title of the work, journal citation and DOI.

\section{References}

[1] Leber, M., Bastič, M., Moody, L., Schmidt Krajnc, M. (2018). A study of the impact of ergonomically designed workplaces on employee productivity, Advances in Production Engineering \& Management, Vol. 13, No. 1, 107117, doi: 10.14743/apem2018.1.277.

[2] Vulanović, S., Delić, M., Kamberović, B., Beker, I., Lalić, B. (2020). Integrated management systems based on risk assessment: Methodology development and case studies, Advances in Production Engineering \& Management, Vol. 15, No. 1, 93-106, doi: 10.14743/apem2020.1.352.

[3] Müngen, U., Gürcanli, G.E. (2005). Fatal traffic accidents in the Turkish construction industry, Safety Science, Vol. 43, No. 5-6, 299-322, doi: 10.1016/j.ssci.2005.06.002.

[4] Rivas, T., Paz, M., Martín, J.E., Matías, J.M., García, J.F., Taboada, J. (2011). Explaining and predicting workplace accidents using data-mining techniques, Reliability Engineering \& System Safety, Vol. 96, No. 7, 739-747, doi: 10.1016/i.ress.2011.03.006

[5] Cheng, C.-W., Leu, S.-S., Lin, C.-C., Fan, C. (2010). Characteristic analysis of occupational accidents at small construction enterprises, Safety Science, Vol. 48, No. 6, 698-707, doi: 10.1016/i.ssci.2010.02.001. 
[6] Alizadeh, S.S., Mortazavi, S.B., Sepehri, M.M. (2015). Assessment of accident severity in the construction industry using the Bayesian theorem, International Journal of Occupational Safety and Ergonomics, Vol. 21, No. 4, 551-557, doi: 10.1080/10803548.2015.1095546.

[7] Szóstak, M. (2018). The application of cluster analysis to identify the occupational profile of people injured in accidents in the Polish construction industry, In: Proceedings of VII International Symposium Actual Problems of Computational Simulation in Civil Engineering, Vol. 456, Novosibirsk, Russian Federation, Article No. 012027, doi: 10.1088/1757-899X/456/1/012027.

[8] Drozd, W. (2017). Identifying and profiling the patterns of construction accidents using affinity analysis, Technical Transactions / Czasopismo Techniczne, Vol. 5, 15-24, doi: 10.4467/2353737XCT.17.065.6422.

[9] Berglund, L., Johansson, M., Nygren, M., Samuelson, B., Stenberg, M., Johansson, J. (2021). Occupational accidents in Swedish construction trades, International Journal of Occupational Safety and Ergonomics, Vol. 27, No. 2, 552561, doi: $10.1080 / 10803548.2019 .1598123$.

[10] Ayhan, B.U., Tokdemir, O.B. (2020). Accident analysis for construction safety using latent class clustering and artificial neural networks, Journal of Construction Engineering and Management, Vol. 146, No. 3, Article No. 04019114, doi: 10.1061/(ASCE)C0.1943-7862.0001762.

[11] Lee, J.Y., Yoon, Y.G., Oh, T.K., Park, S., Ryu, S.I. (2020). A study on data pre-processing and accident prediction modelling for occupational accident analysis in the construction industry, Applied Sciences, Vol. 10, No. 21, Article No. 7949, doi: 10.3390/app10217949.

[12] Zhang, F., Fleyeh, H., Wang, X., Lu, M. (2019). Construction site accident analysis using text mining and natural language processing techniques, Automation in Construction, Vol. 99, 238-248, doi: 10.1016/j.autcon.2018.12. $\underline{016 .}$

[13] Palamara, F., Piglione, F., Piccinini, N. (2011). Self-organizing map and clustering algorithms for the analysis of occupational accident databases, Safety Science, Vol. 49, No. 8-9, 1215-1230, doi: 10.1016/j.ssci.2011.04.003.

[14] Comberti, L., Baldissone, G., Demichela, M. (2015). Workplace accidents analysis with a coupled clustering methods: S.O.M. and K-means algorithms, Chemical Engineering Transactions, Vol. 43, 1261-1266, doi: 10.3303/ CET1543211.

[15] Comberti, L., Demichela, M., Baldissone, G., Fois, G., Luzzi, R. (2018). Large occupational accidents data analysis with a coupled unsupervised algorithm: The S.O.M. K-means method. An application to the wood industry, Safety, Vol. 4, No. 4, Article No. 51, doi: 10.3390/safety4040051.

[16] Comberti, L., Demichela, M., Baldissone, G. (2018). A combined approach for the analysis of large occupational accident databases to support accident-prevention decision making, Safety Science, Vol. 106, 191-202, doi: 10.1016/i.ssci.2018.03.014.

[17] Moura, R., Beer, M., Patelli, E., Lewis, J., Knoll, F. (2017). Learning from accidents: Interactions between human factors, technology and organisations as a central element to validate risk studies, Safety Science, Vol. 99, Part B, 196-214, doi: 10.1016/i.ssci.2017.05.001.

[18] Moura, R., Beer, M., Patelli, E., Lewis, J. (2017). Learning from major accidents: Graphical representation and analysis of multi-attribute events to enhance risk communication, Safety Science, Vol. 99, Part A, 58-70, doi: 10.1016/j.ssci.2017.03.005.

[19] Verma, A., Khan, S.D., Maiti, J., Krishna, O.B. (2014). Identifying patterns of safety related incidents in a steel plant using association rule mining of incident investigation reports, Safety Science, Vol. 70, 89-98, doi: 10.1016/j.ssci. 2014.05.007.

[20] Ghousi, R. (2015). Applying a decision support system for accident analysis by using data mining approach: A case study on one of the Iranian manufactures, Journal of Industrial and Systems Engineering, Vol. 8, No. 3, 59-76.

[21] Sanmiquel, L., Bascompta, M., Rossell, J.M., Anticoi, H.F., Guash, E. (2018). Analysis of occupational accidents in underground and surface mining in Spain using data-mining techniques, International Journal of Environmental Research and Public Health, Vol. 15, No. 3, Article No. 462, doi: 10.3390/ijerph15030462.

[22] Farina, E., Bianco, S., Bena, A., Pasqualini, O. (2019). Finding causation in occupational fatalities: A latent class analysis, American Journal of Industrial Medicine, Vol. 62, No. 2, 123-130, doi: 10.1002/ajim.22936.

[23] Davoudi Kakhki, F., Freeman, S.A., Mosher, G.A. (2019). Segmentation of severe occupational incidents in agribusiness industries using latent class clustering, Applied Sciences, Vol. 9, No. 18, Article No. 3641, doi: 10.3390/ app9183641.

[24] Nowakowska, M., Pajęcki, M. (2020). Applying latent class analysis in the identification of occupational accident patterns, Scientific Papers of Silesian University of Technology - Organization \& Management, No. 146, 339-355, doi: 10.29119/1641-3466.2020.146.25.

[25] Collins, L.M., Lanza, S.T. (2010). Latent class and latent transaction analysis: With applications in the social, behavioral, and health sciences, John Wiley \& Sons, New Jersey, USA, doi: 10.1002/9780470567333.

[26] Kim, S-Y. (2014). Determining the number of latent classes in single- and multiphase growth mixture models, Structural Equation Modeling: A Multidisciplinary Journal, Vol. 21, No. 2, 263-279, doi: 10.1080/10705511.2014. 882690.

[27] Lin, T.H., Dayton, C.M. (1997). Model selection information criteria for non-nested latent class models, Journal of Educational and Behavioral Statistics, Vol. 22, No. 3, 249-264, doi: 10.3102/10769986022003249.

[28] Nylund, K.L., Asparouhov, T., Muthén, B.O. (2007). Deciding on the number of classes in latent class analysis and growth mixture modeling: A Monte Carlo simulation study, Structural Equation Modeling: A Multidisciplinary Journal, Vol. 14, No. 4, 535-569, doi: 10.1080/10705510701575396.

[29] Lanza, S.T., Dziak, J.J., Huang, L., Wagner, A.T., Collins, L.M. (2015). Proc LCA \& Proc LTA Users' Guide (Version 1.3.2), University Park: The Methodology Center, Penn State, from https://www.methodology.psu.edu/, accessed April 10, 2021. 
[30] Ordinance of the Minister of Labour and Social Policy of 7 January 2009 on a statistical accident card at work, Journal of Laws of 2009, No. 14, item 80, as amended, from http://isap.sejm.gov.pl/isap.nsf/download.xsp/WDU20090140080/0/D20090080.pdf, accessed June 24, 2021.

[31] Regulation of the Minister of Family, Labour and Social Policy of 4 June 2019 amending the regulation on a statistical accident card at work, Journal of Laws of 2019, item 1106, as amended, from http://isap.sejm.gov.pl/isap.nsf/download.xsp/WDU20190001106/O/D20191106.pdf, accessed June 24, 2021.

[32] Pajęcki, M. (2020) Bezpieczeństwo pracy w sekcji przetwórstwa przemysłowego w Polsce - stan wypadkowości, In: Knosala, R. (ed.), Inżynieria zarządzania. Cyfryzacja produkcji. Aktualności badawcze 3, PWE, Poland, 12231232.

[33] Chakrabarti, C.G., Chakrabarty, I. (2005). Shannon entropy: Axiomatic characterization and application, International Journal of Mathematics and Mathematical Sciences, Vol. 2005, Article ID 234590, doi: 10.1155/IJMMS. 2005.2847. 


\section{APEM}

\title{
Analiza latentnih razredov za prepoznavo resnosti delovnih nesreč v izbranem poljskem proizvodnem sektorju
}

\author{
Nowakowska, M. ${ }^{a,}{ }^{*}$, Pajęcki, M. ${ }^{b}$
}

aFaculty of Management and Computer Modelling, Kielce University of Technology, Poland bFaculty of Management and Computer Modelling, Kielce University of Technology, Poland

\section{POVZETEK}

Cilj analize je opredelitev profilov delovnih nesreč v proizvodnih podjetjih za pridobitev potrebnega znanja ter za lažjo pripravo in zagotavljanje varnega delovnega okolja. Predmet raziskave so bili kvalitativni podatki, ki označujejo zaposlene, poškodovane $\mathrm{v}$ nesrečah, zabeleženih $\mathrm{v}$ poljskih lesnopredelovalnih podjetjih $\mathrm{v}$ obdobju 10 let. $\mathrm{V}$ raziskavi je bila uporabljena metoda analize latentnih razredov (LCA). Ta tehnika statističnega modeliranja na podlagi vrednosti izbranih kazalnikov (opazovanih spremenljivk) razdeli nabor podatkov v ločene skupine, imenovane latentni razredi, ki omogočajo definiranje vzorcev. Predstavljen je bil postopek, ki podpira odločitev glede števila razredov. Postopek upošteva kakovost modela LCA in razločno ločljivost razredov. Poleg tega je bila predlagana metoda ocenjevanja pomembnosti kazalnikov v opisu vzorcev. Dobljenih je bilo sedem latentnih razredov, ki so prikazani s toplotno karto, kar je omogočilo identifikacijo profilov. Označeni so bili takole: zelo resni, resni, zmerni, manjši (trije latentni razredi), rahli. Podana so bila nekatera priporočila glede okoliščin nezgod pri delu z najhujšimi posledicami za poškodovance.

\section{PODATKI O ČLANKU}

Ključne besede:

Proizvodna industrija;

Nesreče pri delu;

Prepoznava resnosti nesreče;

Modeliranje;

Analiza latentnih razredov (LCA);

Analiza gruč;

Izbira modela

*Kontaktna oseba: spimn@tu.kielce.pl

(Nowakowska, M.)

Zgodovina članka:

Prejet 24. junija 2021

Popravljen 5. decembra 2021

Sprejet 6. decembra 2021

\section{(i)}

Content from this work may be used under the terms of the Creative Commons Attribution 4.0 International Licence (CC BY 4.0). Any further distribution of this work must maintain attribution to the author(s) and the title of the work, journal citation and DO 